\title{
A New Species of Leptolalax from Sarawak, Western Borneo (Anura: Megophryidae)
}

\section{$\operatorname{AUTHOR}(\mathrm{S}):$}

Matsui, Masafumi; Zainudin, Ramlah; Nishikawa, Kanto

\section{CITATION:}

Matsui, Masafumi ... [et al]. A New Species of Leptolalax from Sarawak, Western Borneo (Anura: Megophryidae). Zoological Science 2014, 31(11): 773-779

ISSUE DATE:

2014-11

URL:

http://hdl.handle.net/2433/216902

RIGHT:

(C) 2014 Zoological Society of Japan 


\title{
A New Species of Leptolalax from Sarawak, Western Borneo (Anura: Megophryidae)
}

\author{
Masafumi Matsui $^{1 *}$, Ramlah Zainudin ${ }^{2}$, and Kanto Nishikawa ${ }^{1}$ \\ ${ }^{1}$ Graduate School of Human and Environmental Studies, Kyoto University, Sakyo-ku, Kyoto 606-8501, Japan \\ ${ }^{2}$ Molecular Ecology Laboratory, Faculty of Resource Science and Technology, \\ Universiti Malaysia Sarawak, 94300, Kota Samarahan, Sarawak, Malaysia
}

\begin{abstract}
A new megophryid species is described from southwestern Sarawak, Malaysian Borneo. In appearance, Leptolalax marmoratus sp. nov. is most similar to $L$. hamidi also from southwestern Sarawak, but differs from it by mtDNA sequence, larger body size, and higher dominant frequency of advertisement call. The assumption that more than one species of Leptolalax coexist at one locality in Borneo is supported. The finding of the new species raises the species number of Leptolalax known from Borneo to nine, and the island is thought to be one of the diversification centers of the genus.
\end{abstract}

Key words: acoustics, Borneo, Leptolalax, new species, Southeast Asia, molecular phylogeny

\section{INTRODUCTION}

It is now becoming common to identify cryptic anuran species through molecular phylogenetic methods, but an even more biologically significant method is acoustic analysis. Analyses of call characteristics play an important role in detecting cryptic taxa among frogs, and this is particularly the case in the Southeast Asian megophryid genus Leptolalax Dubois, 1980, whose members are otherwise very difficult to identify (Malkmus and Riede, 1993; Matsui, 1997, 2006; Matsui et al., 2009; Matsui and Dehling, 2012; Dehling and Matsui, 2013; Matsui et al., 2014). Eight species of Leptolalax, L. arayai Matsui, 1997, L. dringi Dubois, 1987, L. fritinniens Dehling and Matsui, 2013, L. gracilis (Günther, 1872), L. hamidi Matsui, 1997, L. maurus Inger, Lakim, Biun, and Yambun, 1997, L. pictus Malkmus, 1992, and $L$. sabahmontanus Matsui, Nishikawa, and Yambun, 2014, have been recognized from the island of Borneo. Call characteristics of all of the named species have been described and proved to be species-specific (Malkmus and Riede, 1993; Matsui, 1997; Malkmus et al., 2002; Sukumaran et al., 2010; Matsui and Dehling, 2012; Dehling and Matsui, 2013; Matsui et al., 2014).

During our field survey in southwestern Sarawak, Malaysian part of Borneo Island (Fig. 1), we collected several Leptolalax specimens that are very similar to $L$. hamidi in color pattern, but which had significantly larger body sizes than that species. Moreover, their calls were higher in frequency than in $L$. hamidi in spite of their larger body size. Detailed analyses of acoustic, morphological, and molecular characteristics have revealed that they represent a distinct species that is different from any other congeners. In this paper, we describe this species as new to science.

\footnotetext{
* Corresponding author. Tel. : : +81-75-753-6846; Fax : +81-75-753-6846; E-mail: fumi@zoo.zool.kyoto-u.ac.jp
}

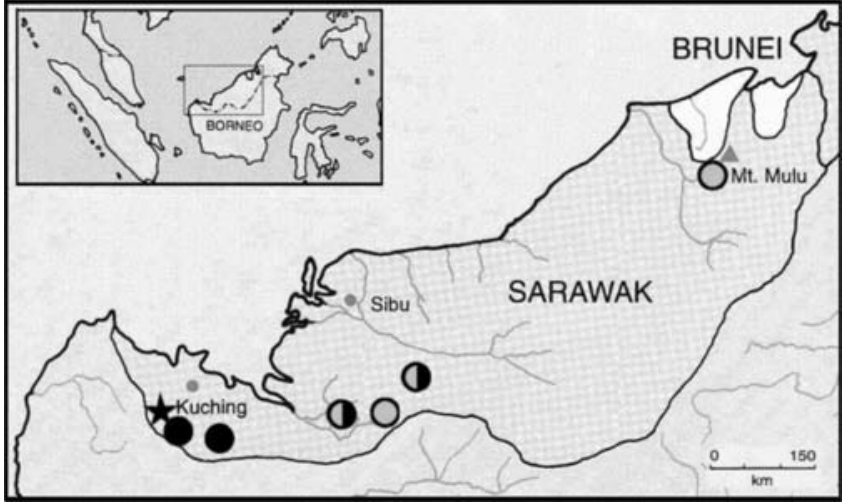

Fig. 1. Map of Sarawak, Malaysian Borneo, showing the known distribution of Leptolalax marmoratus sp. nov. (filled circles), $L$. hamidi (open circles), and literature record of either of the two species (half-filled circles). The filled star indicates the type locality.

\section{MATERIALS AND METHODS}

We collected Leptolalax in southwestern Sarawak (Annah Rais, Padawan; Gunung [= Mount] Penrissen, Padawan; and Ranchan, Serian) during our field survey during 2009-2014. We made recordings of calls in the field using digital recorders (Zoom H2 or Olympus LS11). At the time of recording, we made temperature measurements using a quick-recording thermistor thermometer. We analyzed the recorded calls with SoundEdit Pro (MacroMind-Paracomp, Inc.) and Raven Lite 1.0 for Mac OS X (http://www.birds.cornell.edu/ raven) on a Macintosh computer. Temporal data were obtained from the oscillogram and frequency information was obtained from the audiospectrograms using fast Fourier transformation (1024 point Hanning window).

After recording calls, we collected specimens, took tissues for subsequent biochemical analysis, and fixed the specimens for vouchers. Specimens, fixed in 10\% formalin and later preserved in $70 \%$ ethanol, are stored at the Molecular Ecology Laboratory, Faculty of Resource Science and Technology, Universiti Malaysia Sarawak (UNIMAS), Sarawak Research Collections, Forest Research Center

doi:10.2108/zs140137 
Sarawak (SRC), and Graduate School of Human and Environmental Studies, Kyoto University (KUHE). Twenty body measurements were taken, mainly following Matsui $(1984,1997)$ : (1) snout-vent length (SVL); (2) head length (HL); (3) snout-nostril length (S-NL); (4) nostril-eyelid length (N-EL); (5) snout length (SL); (6) eye length (EL, including eyelid); (7) tympanum-eye length (T-EL); (8) tympanum diameter (TD); (9) head width (HW); (10) internarial distance (IND); (11) interorbital distance (IOD); (12) upper eyelid width (UEW); (13) forelimb length (FLL); (14) lower arm length (LAL); (15) inner palmar tubercle length (IPTL); (16) hindlimb length (HLL); (17) tibia length (TL); (18) foot length (FL); (19) inner metatarsal tubercle length (IMTL); and (20) first toe length (1TOEL). We made all measurements to the nearest $0.1 \mathrm{~mm}$ with dial calipers under a binocular dissecting microscope. We followed Savage (1997) in describing toe-webbing states.

DNA sequence data were obtained from tissue samples preserved in $99 \%$ ethanol. We reconstructed phylogenetic trees from approximately 2300 base pairs (bp) of the partial sequences of mitochondrial $12 S$ and $16 S$ rRNA genes to clarify the genetic structure of six specimens of Leptolalax sp. from Sarawak (KUHE 53191 and 53192 from Annah Rais, Padawan; KUHE 53925 and 54471 from Gunung Penrissen, Padawan; KUHE 53204 and 53227 from Ranchang, Serian). For comparisons, L. hamidi from Bukit Lanjak (KUHE 17545, paratype) was also sequenced. The resultant sequences were deposited in GenBank (AB969287-969292). Published data for each one sample of $L$. arayai (BORNEENSIS 22931 from Liwagu, Kinabalu: AB8475558), L. dringi (KUHE 55610 from Camp 4 of Gunung Mulu: AB847553), L. fritinniens (KUHE 55371 from Headquarters, Gunung Mulu: AB847557), L. gracilis (KUHE 55624 from Camp 1, Gunung Mulu: AB847560), L. maurus (SP 21450 from Kinabalu: AB847559), L. pictus (KUHE 39298 from Poring, Kinabalu: AB847556), and $L$. sabahmontanus (BORNEENSIS 12632 from Liwagu, Kinabalu: AB847551), and outgroup species $L$. heteropus (Boulenger, 1900) (KUHE 15490 from Larut, Peninsular Malaysia: AB847561) and Leptobrachium hasseltii Tschudi, 1838 (KUHE 42820 from Java: AB530424) were used for comparisons. Methods for DNA extraction and, amplification and sequencing of the mtDNA fragments are the same as those reported by Matsui et al. (2010) and Hamidy et al. (2011). The alignment matrix with 2289 mtDNA nucleotide sites was subjected to estimate phylogenetic relationships using maximum likelihood (ML) and Bayesian inference (BI). Pairwise comparisons of uncorrected sequence divergences ( $p$-distance) were also calculated for 16S rRNA. Details for all these procedures are given in Hamidy et al. (2011).

\section{RESULTS}

We obtained $2289 \mathrm{bp}$ of concatenated fragments of mtDNA genes for all samples, including out-groups (Fig. 2), of which sites, 756 were variable, and 398 were parsimoniously informative. The best substitution model was GTR with gamma shape parameter $(G)$ of 0.312 for $M L$ and 0.332 for $\mathrm{BI}$, and the likelihood values (-InLs) of the $\mathrm{ML}$ and $\mathrm{BI}$ trees were 11797.418 and 11817.707 , respectively.

Phylogenetic analyses employing two different optimality criteria yielded nearly identical relationships. As shown in the ML tree in Fig. 2, six specimens of Leptolalax sp. from Sarawak obtained from three localities proved to form a fully supported clade (MLBS $=100$, Bayesian posterior probability $[\mathrm{BPP}]=1.00)$. Leptolalax sp. from Sarawak, $L$. arayai, and $L$. hamidi also formed a fully supported clade, but within this clade, sister species relationship of $L$. arayai and $L$. hamidi was not resolved (MLBS $=63$, BPP $=0.70$ ). The genetic distance (uncorrected p-distance of 16S rRNA) of the clade of Leptolalax sp. from Sarawak from L. hamidi was substantially large, with the mean of $6.0 \%$ (range $=5.9$

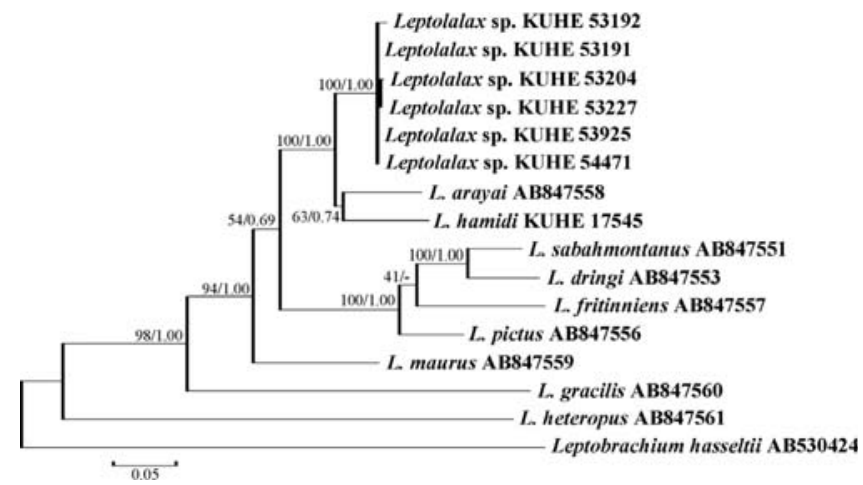

Fig. 2. Maximum likelihood (ML) tree of a $2289 \mathrm{bp}$ sequence of mitochondrial $12 S$ and 16S rRNA for samples of Leptolalax (for sample details, see text). Numbers above or below branches represent bootstrap supports for ML inference and Bayesian posterior probability (ML-BS/BPP).

Table 1. Uncorrected p-distances (in \%) for fragment of $16 \mathrm{~S}$ rRNA among Leptolalax taxa compared.

\begin{tabular}{|c|c|c|c|c|c|c|c|c|c|c|c|c|c|c|c|c|}
\hline & & 1 & 2 & 3 & 4 & 5 & 6 & 7 & 8 & 9 & 10 & 11 & 12 & 13 & 14 & 15 \\
\hline 1 & Leptolalax sp. KUHE 53192 Annah Rais & & & & & & & & & & & & & & & \\
\hline 2 & Leptolalax sp. KUHE 53191 Annah Rais & 0.3 & & & & & & & & & & & & & & \\
\hline 3 & Leptolalax sp. KUHE 53204 Serian & 0.3 & 0 & & & & & & & & & & & & & \\
\hline 4 & Leptolalax sp. KUHE 53227 Serian & 0.3 & 0 & 0 & & & & & & & & & & & & \\
\hline 5 & Leptolalax sp. KUHE 53925 Penrissen & 0.3 & 0 & 0 & 0 & & & & & & & & & & & \\
\hline 6 & Leptolalax sp. KUHE 54471 Penrissen & 0.3 & 0 & 0 & 0 & 0 & & & & & & & & & & \\
\hline 7 & L. hamidi KUHE 17545 & 6.2 & 5.9 & 5.9 & 5.9 & 5.9 & 5.9 & & & & & & & & & \\
\hline 8 & L. arayai BORN 22931 & 5.7 & 5.5 & 5.5 & 5.5 & 5.5 & 5.5 & 6.0 & & & & & & & & \\
\hline 9 & L. sabahmontanus BORN 12632 & 10.9 & 10.7 & 10.7 & 10.7 & 10.7 & 10.7 & 11.1 & 11.5 & & & & & & & \\
\hline 10 & L. dringi KUHE 55610 & 11.1 & 10.9 & 10.9 & 10.9 & 10.9 & 10.9 & 11.6 & 11.6 & 5.0 & & & & & & \\
\hline 11 & L. fritinniens KUHE 55371 & 11.5 & 11.3 & 11.3 & 11.3 & 11.3 & 11.3 & 11.9 & 11.7 & 6.8 & 7.2 & & & & & \\
\hline 12 & L. pictus KUHE 39298 & 10.1 & 9.8 & 9.8 & 9.8 & 9.8 & 9.8 & 10.9 & 10.5 & 6.1 & 5.9 & 6.3 & & & & \\
\hline 13 & L. maurus SP 21450 & 9.9 & 9.7 & 9.7 & 9.7 & 9.7 & 9.7 & 10.5 & 9.7 & 11.1 & 11.6 & 12.0 & 11.2 & & & \\
\hline 14 & L. gracilis KUHE 55624 & 15.2 & 15.0 & 15.0 & 15.0 & 15.0 & 15.0 & 15.6 & 15.0 & 14.7 & 14.7 & 15.3 & 13.5 & 14.4 & & \\
\hline 15 & L. heteropus KUHE 15490 & 21.0 & 20.9 & 20.9 & 20.9 & 20.9 & 20.9 & 20.5 & 20.9 & 20.1 & 20.1 & 19.8 & 19.1 & 20.9 & 21.1 & \\
\hline 16 & Leptobrachium hasselti KUHE 42820 & 21.6 & 21.4 & 21.4 & 21.4 & 21.4 & 21.4 & 21.5 & 21.7 & 23.1 & 23.5 & 22.5 & 21.9 & 21.8 & 23.3 & 23.2 \\
\hline
\end{tabular}




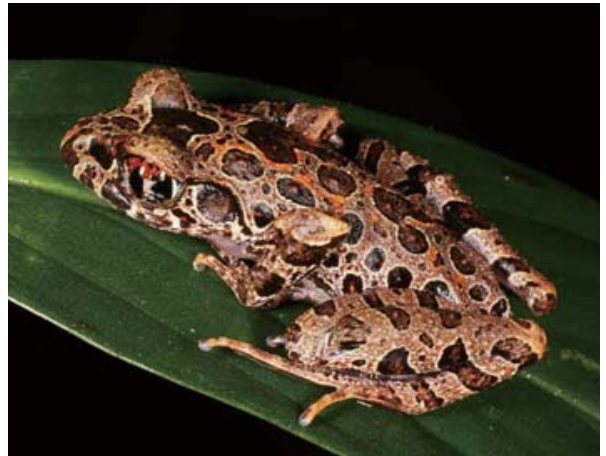

Fig. 3. Dorsolateral view of a male paratype of Leptolalax marmoratus sp. nov. (SRC unnumbered [former KUHE 53192]) from the type locality.

6.2\%: Table 1), and was even larger than that from $L$. arayai (mean $=5.5 \%$, range $=5.5-5.7 \%$ : Table 1$)$. These values approximated the distances between distinctly different species $L$. dringi and $L$. sabahmontanus $(5.0 \%)$, and $L$. fritinniens and $L$. pictus $(6.3 \%)$.

In addition to genetic separation, the specimens of Leptolalax sp. from Sarawak are also clearly separated morphologically and acoustically from all the other congeners. We thus describe Leptolalax sp. from Sarawak as follows:

\section{SYSTEMATICS}

\section{Leptolalax marmoratus sp. nov.}

(Figs. 4, 5)

\section{Diagnosis}

A large-sized form of the genus Leptolalax (males 32.3$38.0 \mathrm{~mm}$, females $41.4-46.8 \mathrm{~mm}$ in SVL); tibiotarsal articulation of adpressed limb at least reaching nostril; differing from all the other congeners except for $L$. hamidi and $L$. pictus by unique dorsal coloration, with large dark brown markings on a tan to light brown background of dorsum, and creamy ventrum without dark markings; from very similar $L$. hamidi, it differs in its much larger body size (males 28.7$28.8 \mathrm{~mm}$, females $35.1-37.4 \mathrm{~mm}$ SVL in L. hamidi), presence of discrete dark spots posterior to sacrum, and higher dominant frequency of advertisement call (7.4 to $8.2 \mathrm{kHz}$ vs. 6.7 to $7.3 \mathrm{kHz}$ in $L$. hamidi) in spite of larger body size; it overlaps $L$. pictus in body size (males $29.8-34.0 \mathrm{~mm}$ and females $38.6-42.3 \mathrm{~mm}$ ) but differs by much more conspicuous, discrete dorsal markings, including a large dark marking on top of snout, and higher dominant frequency of advertisement call (snout marking faint and dominant frequency 6.8$7.2 \mathrm{kHz}$ in L. pictus).

\section{Etymology}

The specific epithet is an adjective from Greek "marmaro", meaning marble, in reference to beautifully blotched dorsum of the new species.

\section{Holotype}

KUHE 53193, an adult male from Annah Rais, Padawan, Kuching Division, Sarawak, Malaysia $\left(01^{\circ} 08^{\prime} 35^{\prime \prime}\right.$ $\mathrm{N}, 110^{\circ} 15^{\prime} 47^{\prime \prime} \mathrm{E}, 71 \mathrm{~m}$ a.s.l.), collected on 28 August 2009

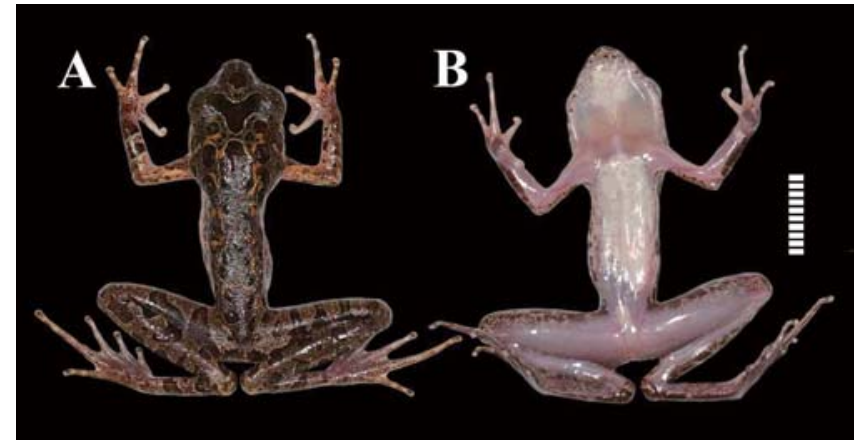

Fig. 4. Dorsal (A) and ventral (B) views of male holotype of Leptolalax marmoratus sp. nov. (KUHE 53193). Scale bar $=10 \mathrm{~mm}$.

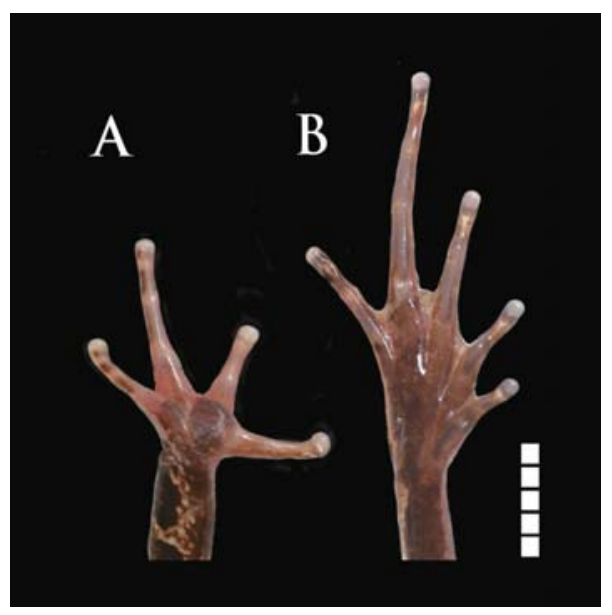

Fig. 5. Ventral view of right hand (A) and foot (B) of male holotype of Leptolalax marmoratus sp. nov. (KUHE 53193). Scale bar $=5 \mathrm{~mm}$.

by M. Matsui.

\section{Paratypes}

All from Sarawak. USM GR 006, 095, two females from

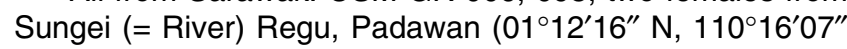
E) collected on 16 and 18 August 2009 by R. Zainudin; SRC unnumbered (former KUHE 48804, one male, collected on 7 March 2014 by M. K. Nishikawa from Ranchan, Serian, Samarahan Division $\left[01^{\circ} 08^{\prime} 28^{\prime \prime} \mathrm{N}, 110^{\circ} 34^{\prime} 59^{\prime \prime} \mathrm{E}, 52 \mathrm{~m}\right.$ a.s.I.], and former KUHE 53192, one male, data same as the holotype); KUHE 53191, 53194, 53195, two males and one female, data same as the holotype; KUHE 48805, 48821, 48822, two males and one female, collected on 7 March 2014 by M. Matsui, K. Nishikawa, and K. Eto, KUHE 53204 , 53227, 53228, 53229, three males and one female, collected on 29 August 2009 by M. Matsui and K. Nishikawa from Ranchan, Serian; KUHE 48516, 48517, 48521, 48622, two males and two females, collected between 19-21 December 2013 by M. Matsui, K. Nishikawa, and T. Shimada at $01^{\circ} 08^{\prime} 34^{\prime \prime} \mathrm{N}, 110^{\circ} 13^{\prime} 37^{\prime \prime} \mathrm{E}, 432 \mathrm{~m}$ a.s.I., KUHE 53924 53925, two males, collected on 2 September 2010 by $M$. Matsui and K. Nishikawa at $01^{\circ} 07^{\prime} 31^{\prime \prime} \mathrm{N}, 110^{\circ} 12^{\prime} 49^{\prime \prime} \mathrm{E}$, $905 \mathrm{~m}$ a.s.I., and KUHE 54471, one male, collected on 21 February 2012 by K. Nishikawa at $01^{\circ} 07^{\prime} 31^{\prime \prime} \mathrm{N}, 110^{\circ} 12^{\prime} 49^{\prime \prime}$ E, $905 \mathrm{~m}$ a.s.I. on Gunung Penrissen, Kuching Division. 


\section{Referred specimens}

KUHE 48624, one newly metamorphosed juvenile from Gunung Penrissen $\left(01^{\circ} 08^{\prime} 38^{\prime \prime} \mathrm{N}, 110^{\circ} 13^{\prime} 45^{\prime \prime} \mathrm{E}, 455 \mathrm{~m}\right.$ a.s.I.); KUHE 48683, one juvenile from Ranchan, Serian $\left(01^{\circ} 08^{\prime} 28^{\prime \prime} \mathrm{N}, 110^{\circ} 34^{\prime} 59^{\prime \prime} \mathrm{E}, 52 \mathrm{~m}\right.$ a.s.l.).

\section{Description of holotype (measurements in $\mathbf{~ m m}$ )}

SVL 36.2; habitus slender (Fig. 4); head longer (HL 14.2, 39.2\%SVL) than broad (HW 11.4, 31.5\%SVL); snout obtusely pointed, rounded in profile, projecting beyond lower jaw; eye large, length (EL 5.6, 15.5\%SVL) slightly greater than snout length (SL 5.3, 14.6\%SVL); canthus distinct, slightly constricted; lore slightly oblique, concave; nostril lateral, below canthus, distinctly closer to tip of snout than to eye; internarial distance (IND $3.0,8.3 \% \mathrm{SVL}$ ) subequal to interorbital distance (IOD 2.9, 8.0\%), latter much narrower than upper eyelid (UEW 3.9, 10.8\%); pineal spot absent; tympanum distinct, diameter (TD 2.8, 7.7\%SVL) half that of eye, and separated from eye by one-third of tympanic diameter (T-EL 1.1, 3.0\%SVL); vomerine teeth absent; tongue notched, without papillae; vocal sac subgular, bipartite, consisting of two ventrolaterally situated parts; small vocal openings posterior to rictus, close to eustachian tube openings.

Forelimb long (FLL 27.2, 75.1\%SVL; LAL 18.9, $52.2 \% S V L)$ and slender; fingers slender, unwebbed; finger length formula: I $<$ II $<$ IV < III (Fig. 5A), first finger slightly shorter than second, latter slightly shorter than fourth; finger tips slightly swollen; no fringes of skin along fingers; inner palmar tubercle large (IPTL 2.9, 8.0\%SVL), not extending onto first metacarpal and smaller outer palmar tubercle; subarticular tubercles indistinct, replaced by indistinct, low callous tissue; nuptial pads absent.

Hindlimb long (HLL 62.8, 173.5\%SVL); tibia relatively long (TL 20.2, 55.8\%SVL), heels overlapping when limbs are held at right angles to body; tibiotarsal articulation of adpressed limb reaching beyond snout; foot (FL 16.9, $46.7 \% \mathrm{SVL}$ ) shorter than tibia; toe length formula I $<$ II $<\mathrm{V}<$ III < IV; third toe longer than fifth; toe tips similar to those of fingers; webbing confined to bases of toes (Fig. 5B), formula: I $1 \frac{3}{4}-2+$ II $14 / 5-3$ III $2^{2} / 3-3^{3} / 4$ IV $4-2^{2} / 3$ V; toes without lateral fringes; subarticular tubercles obscure, but elongate, replaced by low callous tissue, a relatively short one on each of second, third, and fifth toes, larger ones on fourth toe; inner metatarsal tubercle low, length (IMTL 2.1, $5.8 \%$ SVL) about one-third of first toe (1TOEL 3.0, 8.3\%SVL); no outer metatarsal tubercle.

Skin dorsally nearly smooth, scattered with small tubercles of varying sizes; top of snout smooth but eyelid with small tubercles; a low, supratympanic ridge from eye to axilla; sides with larger tubercles; chest and abdomen smooth; supra-axillary gland small, white in color; pectoral gland and ventrolateral glandular ridges absent; femoral gland indistinct, in a large white blotch.

\section{Color}

In life tan dorsally on head and body, with large, discrete, cream-edged, dark brown spots, including interorbital, frontal, canthal, and post-sacral spots; pinkish tinges between spots (Fig. 4A); tympanum brown edged black above and white below; lips barred with black; sides with dark spots; groin with dark spot not extending onto thigh; limbs marked dorsally with alternating light and dark brown crossbars; no light-colored area around the elbow, between upper and lower arms; throat largely unpigmented posterolaterally; chest, and abdomen immaculate white (Fig. 4B); iris clay-white in ventral two- thirds, reddish in dorsal third, with inner edge around pupil ruby-red. In preservative, color and pattern have slightly faded in preservative, but not obviously changed. The pinkish tinges between dorsal dark markings have disappeared, and upper and lower halves of iris have become indistinguishable.

\section{Variation}

Individuals of the type series are generally similar to each other in morphology. Variation in size and body proportions is given in Table 2. Specimens from three different localities do not differ in size and proportions of body. Females (SVL 41.4-46.8 mm) are significantly larger than males (SVL 32.3-38.0 mm; t-test, $P<0.01$ ), but the sexes do not differ in all morphometric values relative to SVL (Dunn's multiple comparisons test, $P>0.05$ ). Tibiotarsal articulation of adpressed limb reaches nostril (in $30.8 \%$ of total individuals examined), tip of snout (23.1\%), and beyond snout $(46.2 \%)$ in males, and between anterior corner of eye and nostril (28.6\%), nostril (14.3\%), nostril to tip of snout $(14.3 \%)$, and tip of snout $(42.9 \%)$ in females. Dark brown marking on dorsum slightly varies in the size and shape.

\section{Eggs and larvae}

The diameter of 12 ova from ovary of KUHE 53195 ranged from 1.28-1.59 (mean $\pm \mathrm{SD}=1.47 \pm 0.10) \mathrm{mm}$. Both animal and vegetal poles were uniformly cream in color. Nothing is known about larvae.

\section{Call characteristics}

The temporal and the frequency characteristics of advertisement calls are nearly similar among individuals from three localities. Calls of a male (KUHE 48805), recorded at Ranchan, Serian on 7 March 2014 at an air temperature of $26.4^{\circ} \mathrm{C}$, were analyzed in detail. The calls lasted $4.7 \pm 2.1$ (mean \pm SD; 1.9-6.7, $n=6$ ) s with an interval of $1.6 \pm 0.1(1.4-1.7, n=5) \mathrm{s}$. The call consisted of long series of notes (Fig. 6A), the number of which within a series was $58.8 \pm 25.5(24-83, n=15)$. Note repetition rate was $12.2 \pm$ $0.1(12.0-12.3, n=6)$ per s. Individual notes lasted $27.9 \pm$ $2.1(24-32, n=15) \mathrm{ms}$ and were separated from each other by an interval of $53.9 \pm 3.1(46-59, n=14) \mathrm{ms}$. Each note was composed of several indistinct pulses (Fig. 6F). Marked frequency modulation was always observed within a note (Fig. 6E). The dominant frequency at the beginning was $8.03 \pm 0.18(7.83-8.55, n=15) \mathrm{kHz}$ and decreased towards the end of the note to $7.55 \pm 0.14(7.43-7.99, n=15) \mathrm{kHz}$. The frequency difference between the beginning and the end of the note was $0.48 \pm 0.14(0.16-0.64, n=15) \mathrm{kHz}$. Usually, the first note of a series was higher in frequency than the subsequent ones (Fig. 6A, C). Irregular intensity modulation was observed within a single call (Fig. 6A).

\section{Comparisons}

Leptolalax marmoratus differs from congeneric species occurring outside Borneo in the same manner as in $L$. 
Table 2. Measurements in adults of Leptolalax marmoratus sp. nov. and $L$. hamidi. SVL (mean $\pm \mathrm{SD}$, in $\mathrm{mm}$ ) and medians of ratios (R) of other characters to SVL, followed by ranges in parenthesis. See text for character abbreviations.

\begin{tabular}{|c|c|c|c|c|}
\hline & \multicolumn{2}{|c|}{ L. marmoratus } & \multicolumn{2}{|c|}{ L. hamidi } \\
\hline & $14 \mathrm{M}$ & $7 F$ & $2 \mathrm{M}$ & $3 F$ \\
\hline \multirow[t]{2}{*}{ SVL } & $34.7 \pm 1.63$ & $44.2 \pm 1.79$ & 28.8 & $36.3 \pm 1.15$ \\
\hline & (32.3-38.0) & (41.4-46.8) & $(28.7-28.8)$ & $(35.1-37.4)$ \\
\hline \multirow[t]{2}{*}{$\mathrm{RHL}$} & 38.5 & 37.3 & 40.2 & 39.3 \\
\hline & (37.2-40.5) & (35.0-39.7) & (39.9-40.4) & $(35.0-39.6)$ \\
\hline \multirow[t]{2}{*}{ RS-NL } & 5.8 & 5.31 & 6.4 & 6.0 \\
\hline & $(5.3-6.6)$ & $(4.7-6.2)$ & $(5.6-7.3)$ & $(5.9-7.7)$ \\
\hline \multirow[t]{2}{*}{ RN-EL } & 8.3 & 8.6 & 8.7 & 8.0 \\
\hline & $(7.0-9.4)$ & $(7.5-9.4)$ & $(8.0-9.4)$ & $(7.4-9.7)$ \\
\hline \multirow[t]{2}{*}{ RSL } & 13.7 & 13.9 & 13.9 & 14.0 \\
\hline & $(13.2-15.2)$ & $(12.8-14.6)$ & $(12.8-15.0)$ & $(13.7-14.4)$ \\
\hline \multirow[t]{2}{*}{ REL } & 15.5 & 14.4 & 17.0 & 15.4 \\
\hline & $(14.3-17.1)$ & $(13.2-15.5)$ & $(16.7-17.4)$ & $(14.6-16.0)$ \\
\hline \multirow[t]{2}{*}{ RT-EL } & 2.7 & 3.5 & 2.7 & 2.7 \\
\hline & $(2.3-4.2)$ & $(2.6-4.5)$ & $(2.6-2.8)$ & $(2.3-3.2)$ \\
\hline \multirow[t]{2}{*}{ RTD } & 7.2 & 6.6 & 8.7 & 7.2 \\
\hline & $(6.6-9.0)$ & $(5.4-7.8)$ & $(8.3-9.1)$ & (6.3-8.5) \\
\hline \multirow[t]{2}{*}{$\mathrm{RHW}$} & 31.5 & 32.3 & 31.6 & 33.4 \\
\hline & $(30.4-34.2)$ & $(31.1-33.6)$ & $(30.7-32.5)$ & $(33.0-34.5)$ \\
\hline \multirow[t]{2}{*}{ RIND } & 8.4 & 7.7 & 8.7 & 8.2 \\
\hline & $(7.0-9.4)$ & $(6.5-8.5)$ & $(8.7-8.7)$ & $(7.0-8.5)$ \\
\hline \multirow[t]{2}{*}{ RIOD } & 8.4 & 7.5 & 10.1 & 7.2 \\
\hline & $(6.0-9.7)$ & $(6.8-9.1)$ & $(9.4-10.8)$ & $(6.3-8.5)$ \\
\hline \multirow[t]{2}{*}{ RUEW } & 11.3 & 11.1 & 11.8 & 11.1 \\
\hline & $(10.2-13.7)$ & $(10.4-13.0)$ & $(11.5-12.2)$ & $(11.0-11.5)$ \\
\hline \multirow[t]{2}{*}{ RFLL } & 70.7 & 70 & 71.5 & 78.3 \\
\hline & $(68.9-75.4)$ & $(69.4-76.2)$ & (69.7-73.3) & $(71.7-79.1)$ \\
\hline \multirow[t]{2}{*}{ RLAL } & 53.1 & 53.2 & 52.2 & 53.0 \\
\hline & $(52.1-57.2)$ & $(51.3-55.8)$ & $(51.2-53.1)$ & $(50.8-57.8)$ \\
\hline \multirow[t]{2}{*}{ RIPTL } & 7.5 & 7.5 & 8.0 & 7.1 \\
\hline & $(6.6-9.9)$ & $(5.3-10.0)$ & $(7.7-8.3)$ & $(7.0-7.7)$ \\
\hline \multirow[t]{2}{*}{ RHLL } & 173.5 & 177.2 & 172.7 & 176.4 \\
\hline & $(168.5-185.6)$ & (163.0-181.7) & $(170.0-175.3)$ & $(174.3-184.6)$ \\
\hline \multirow[t]{2}{*}{ RTL } & 55.6 & 56.2 & 55.1 & 55.1 \\
\hline & $(52.4-58.4)$ & $(51.7-57.6)$ & $(54.4-55.9)$ & $(54.1-59.3)$ \\
\hline \multirow[t]{2}{*}{ RFL } & 46.4 & 47.8 & 45.0 & 48.1 \\
\hline & $(44.3-50.2)$ & $(43.5-49.3)$ & $(44.6-45.5)$ & $(44.9-49.6)$ \\
\hline \multirow[t]{2}{*}{ RIMTL } & 5.7 & 5.3 & 5.0 & 5.5 \\
\hline & $(4.5-6.3)$ & $(4.6-6.1)$ & $(4.9-5.2)$ & $(5.1-6.1)$ \\
\hline \multirow[t]{2}{*}{ R1TOEL } & 7.5 & 7.7 & - & 8.7 \\
\hline & $(7.2-9.2)$ & $(7.3-8.8)$ & - & $(8.0-9.4)$ \\
\hline
\end{tabular}

fritinniens (Dehling and Matsui, 2013) and L. sabahmontanus (Matsui et al., 2014), and comparisons with Bornean species are pertinent. Leptolalax marmoratus morphologically differs from all the described Bornean species in the following ways. By the absence of ventral markings, it resembles $L$. pictus, $L$. hamidi, and $L$. arayai. Especially, the new species closely resembles $L$. hamidi by having large dark brown dorsal markings with light outlines. However, from $L$. hamidi, $L$. marmoratus differs by having a larger body size, male SVL 32.3-38.0 mm, female 41.4-46.8 $\mathrm{mm}$ in SVL, and presence of discrete dark spots posterior to sacrum (vs. 28.7-28.8 $\mathrm{mm}$, female $35.1-37.4 \mathrm{~mm}$, a faint dark spot sometimes
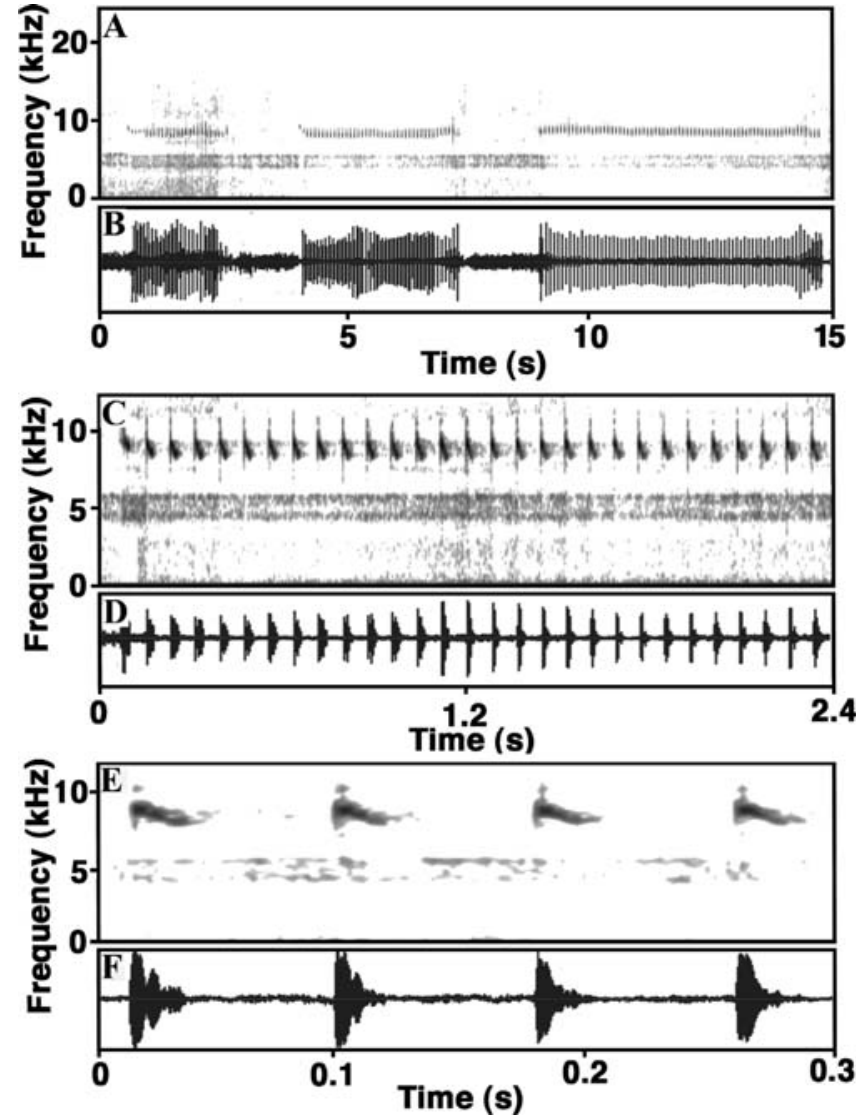

Fig. 6. Sonogram (A, C, E) and wave form (B, D, F) showing advertisement calls of a paratype of Leptolalax marmoratus sp. nov. (KUHE 48805) from Ranchan, Serian, recorded at an air temperature of $26.4^{\circ} \mathrm{C}$.

present between sacrum and cloaca in $L$. hamidi). It differs from $L$. arayai also by the larger body size (male SVL 29.2$32.0 \mathrm{~mm}$ in $L$. arayai), lack of strongly shagreened back, presence of dorsal markings, and absence of flush color on ventral side of legs and groin (vs. dorsum tuberculated, without conspicuous markings, venter yellow, and groin and ventral sides of limbs orange in $L$. arayai). Leptolalax marmoratus resembles $L$. pictus in the body size (male SVL 29.8-34.0 mm SVL in L. pictus) and possession of dark brown markings with conspicuous thin light outlines. However, the new species differs from $L$. pictus by having much more conspicuous, discrete dorsal markings, especially a dark marking on top of the snout, which is as large as the tympanum and as distinct as the interorbital marking (vs. dorsal markings less conspicuous, and sometimes not discrete, and a marking on the snout is faint and much less marked than the interorbital marking in L. pictus).

The white ventrum without markings clearly differentiates $L$. marmoratus from $L$. dringi, $L$. sabahmontanus, $L$. maurus, $L$. gracilis and $L$. fritinniens, all of which have more or less developed ventral dark marking or a dark brown to black ventrum. Of these, the new species is larger than $L$. dringi, L. sabahmontanus, and L. maurus (male SVL 32.3$38.0 \mathrm{~mm}$ vs., $26.6-31.3 \mathrm{~mm}$ in $L$. dringi, $25.4-27.9 \mathrm{~mm}$ in $L$. sabahmontanus, and $25.0-26.9 \mathrm{~mm}$ in L. maurus), but is 
similar to $L$. gracilis and L. fritinniens in body size (male SVL $31.1-39.2 \mathrm{~mm}$ in $L$. gracilis and $27.4-34.8 \mathrm{~mm}$ in L. fritinniens). Furthermore, the new species differs from $L$. dringi, L. sabahmontanus, L. maurus, and L. gracilis by having a bipartite vocal sac in males (vs. medially arranged single vocal sac in $L$. dringi, $L$. sabahmontanus, $L$. maurus, and $L$. gracilis). Leptolalax fritinniens has a bipartite vocal sac like the new species, but the body coloration is completely different from it.

The new species also differs from the known Bornean congeners acoustically. By having clear frequency modulation within a note, the new species differs $L$. sabahmontanus, $L$. dringi, $L$. arayai, $L$. maurus, and $L$. gracilis that have calls lacking frequency modulation and lower dominant frequency than the new species $\left(7.43-8.22 \mathrm{kHz}\right.$ at $26.4^{\circ} \mathrm{C}$ vs. $6.90-$ $7.35 \mathrm{kHz}$ at $17.2-17.7^{\circ} \mathrm{C}$ in $L$. sabahmontanus; $6.05-6.40$ $\mathrm{kHz}$ at unknown temperature in $L$. dringi; $5.40-5.90 \mathrm{kHz}$ at $17.4^{\circ} \mathrm{C}$ in $L$. arayai; $5.15 \mathrm{kHz}$ at unknown temperature in $L$. maurus; $2.60-2.80 \mathrm{kHz}$ at $20.0-26.2^{\circ} \mathrm{C}$ in $L$. gracilis). It resembles $L$. hamidi, $L$. pictus, and $L$. fritinniens in having clear frequency modulation within a note, but the dominant frequency of the call of the new species is higher than that of $L$. hamidi $\left(6.70-7.30 \mathrm{kHz}\right.$ at $\left.22.9-24.1^{\circ} \mathrm{C}\right)$ and $L$. pictus (6.80-7.15 kHz at $\left.19-22^{\circ} \mathrm{C}\right)$, although it overlaps $L$. fritinniens $\left(7.25-9.20 \mathrm{kHz}\right.$ at $\left.24.3-24.9^{\circ} \mathrm{C}\right)$.

\section{Range}

Southwestern region of Sarawak (Fig. 1): Besides the type locality, Annah Rais, Padawan, Kuching Division, the species was recorded from Sungei Regu, Padawan; Ranchan, Serian, Samarahan Division; Gunung Penrissen, Kuching Division. The known localities range $52-905 \mathrm{~m}$ in altitude.

\section{Natural history}

At all three localities, males of $L$. marmoratus sp. nov. were calling at night on the shrubs 1-50 m from streams (width $<10 \mathrm{~m}$ ). Breeding season seems to last long, and calls were heard from late February to early March, from late August to early September, and in late December. At Padawan, two females were found on rocks, one $2 \mathrm{~m}$ from a stream, and another in a stream in mid August, and one female was observed to approach to a calling male in late August. Species associated with the new species were Ansonia spinulifer (Mocquard, 1890), Phrynoidis asper (Gravenhorst, 1829), Leptobrachella mjobergi Smith, 1925, Leptolalax gracilis (Günther, 1872), Ingerana baluensis (Boulenger, 1896), Limnonectes khasianus (Anderson, 1871), L. leporinus Andersson, 1923, Hylarana raniceps (Peters, 1871), Odorrana hosii (Boulenger, 1891), Meristogenys jerboa (Günther, 1872), Staurois guttatus, and Kurixalus appendiculatus (Günther, 1858).

\section{DISCUSSION}

Generally, a larger male frog, with a larger larynx, has a call of lower frequency than a smaller conspecific (e.g., Ryan, 1980), and this holds for interspecifically in some frog groups (e.g., Blair, 1964). However, this seems to be not the case between the new species and $L$. hamidi, which are very similar in general morphology but differ in body size. As shown above, the dominant frequency of $6.70-7.30 \mathrm{kHz}$ in L. hamidi (Matsui, 1997) with male body size of 28.7-28.8 $\mathrm{mm}$ are lower than those found in the new species (7.43$8.22 \mathrm{kHz}$ ), notwithstanding larger body size of the latter species (male SVL 32.3-38.0 mm). Actually, the male SVL and dominant frequency of the mating call do not correlate in the known species of Bornean Leptolalax (detailed data shown above). Except for $L$. gracilis (male SVL 31.1-39.2 mm, 2.60-2.80 kHz), larger species like L. marmoratus sp. nov. have even higher frequencies than the smaller species like L. maurus (25.0-26.9 mm, $5.15 \mathrm{kHz})$.

In his description of $L$. hamidi, Matsui (1997) erroneously cited Inger et al.'s (1995) data for body size range of the species. Leptolalax sp. (morphotype from Sarawak with non-spotted venter) reported by Inger et al. (1995) seems to include both $L$. hamidi and the present new species, since the body size given by Inger et al. (males $28.7-31.3 \mathrm{~mm}$, females $36.1-42.8 \mathrm{~mm}$ in SVL) overlaps that of $L$. hamidi (males 28.7-28.8 mm, females 35.1-37.4 mm: Matsui, 1997 and newer data) and also the present new species (males 32.3-38.0 mm, females 41.4-46.8 mm).

Leptolalax sp. (morphotype from Sarawak with nonspotted venter) of Inger et al. (1995) was recorded from headwaters of Sungai Sekerang, Second Division (= Sri Aman Division), and Nanga Tekalit, Kapit District, Seventh Division (= Kapit Division) (Fig. 1). Of these, Sungai Sekerang is close to the type locality of $L$. hamidi, but Nanga Tekalit is further northeast from there. We recently found $L$. hamidi on Gunung Mulu, northern Sarawak, which is far distant from the type locality (Matsui, unpublished data). Thus the range of $L$. hamidi seems wide and may overlap that of the new species.

In all the three known localities, the new species is syntopic with $L$. gracilis, with a similar body size but calls with much lower frequency. This differential acoustic trait would likely prohibit interspecific hybridization between them, working as a pre-mating reproductive isolation mechanism. Therefore, it is possible that the new species and $L$. hamidi occur syntopically because of their different call characteristics.

The finding of $L$. marmoratus $\mathrm{sp}$. nov. raises the species number of Leptolalax known from Borneo to nine, and our earlier assumption that the island of Borneo is one of the diversification centers of the genus (Dehling and Matsui, 2013) is further strengthened. Similarly, another hypothesis that coexistence of more than one species of Leptolalax at one locality is common in northwestern Borneo (Matsui et al., 2014) can be applied to southwestern region of the island, and also would hold for the entire island, including hitherto little surveyed Indonesian regions of Kalimantan.

\section{ACKNOWLEDGMENTS}

The field survey in Sarawak by MM and $\mathrm{KN}$ was made under research permissions of Pejabat Jabatan Perhutanan (NPW. 907.4.4(V)-93 and NCCD.907.4.4(Jld.VI)-122). The Sarawak Forestry Corporation and the Sarawak Biodiversity Centre kindly provided facilities for conducting research. We are grateful to the following for their encouragements and/or permission to conduct research and export specimens: Datu Haji Len Talif Salleh, Haji ali Bin Yusop, Marker Nyogin, Mohd. Shabudin Sabki, Uning, Haji Abang Mohamad Mohtar Bin Abang Pawozan, Paulus Ak Meleng, and Takao Ichioka. MM and KN thank Koshiro Eto, Tsutomu Hikida, Tomohiko Shimada, and Siew Teck Yeo for field companionship, and Amir Hamidy, Koshiro Eto, and Norihiro Kuraishi for help in the 
laboratory. Field trips by MM and KN were made possible by grants from The Monbusho through the Japan Society for the Promotion of Science (Field Research, Nos. 20405013 and 23405014).

\section{REFERENCES}

Blair WF (1964) Evolution at populational and intrapopulational levels: isolating mechanisms and interspecies interactions in anuran amphibians. Quart Rev Biol 39: 333-334

Dehling JM, Matsui M (2013) A new species of Leptolalax (Anura: Megophryidae) from Gunung Mulu National Park, Sarawak, East Malaysia (Borneo). Zootaxa 3670: 33-44

Hamidy A, Matsui M, Shimada T, Nishikawa K, Yambun P, Sudin A, et al. (2011) Morphological and genetic discordance in two species of Bornean Leptobrachium (Amphibia, Anura, Megophryidae). Mol Phyl Evol 61: 904-913

Inger RF, Stuebing RB, Tan FL (1995) New species and new records of anurans from Borneo. Raffles Bull Zool 43: 115-131

Malkmus R, Riede K (1993) Nachtrag zu Leptolalax pictus Malkmus, 1992 (Anura: Pelobatidae). Sauria Berlin 15: 7-9

Malkmus R, Manthey U, Vogel G, Hoffman P, Kosuch J (2002) Amphibians and Reptiles of Mount Kinabalu (North Borneo). ARG Gantner, Ruggell

Matsui M (1984) Morphometric variation analyses and revision of the Japanese toads (Genus Bufo, Bufonidae). Contrib Biol Lab Kyoto Univ 26: 209-428

Matsui M (1997) Call characteristics of Malaysian Leptolalax with a description of two new species (Anura: Pelobatidae). Copeia 1997: 158-165

Matsui M (2006) Three new species of Leptolalax from Thailand (Amphibia, Anura, Megophryidae). Zool Sci 23: 821-830

Matsui M, Dehling M (2012) Notes on an enigmatic Bornean megophryid, Leptolalax dringi Dubois, 1987 (Amphibia: Anura). Zootaxa 3317: 49-58

Matsui M, Belabut DM, Ahmad N, Yong H-S (2009) A new species of Leptolalax (Amphibia, Anura, Megophryidae) from Peninsular Malaysia. Zool Sci 26: 243-247

Matsui M, Hamidy A, Murphy RW, Khonsue W, Yambun P, Shimada $\mathrm{T}$, et al. (2010) Phylogenetic relationships of megophryid frogs of the genus Leptobrachium (Amphibia, Anura) as revealed by mtDNA gene sequences. Mol Phyl Evol 56: 259-272

Matsui M, Nishikawa K, Yambun P (2014) A new Leptolalax from mountains of Sabah, Borneo (Amphibia, Anura, Megophryidae). Zootaxa 3753: 440-452

Ryan MJ (1980) Female mate choice in a Neotropical frog. Science 209: 523-525

Savage JM (1997) Digital webbing formulae for anurans: a refinement. Herpetol Rev 28: 131

Sukumaran J, Das I, Haas A (2010) Description of the advertisement calls of some Bornean frogs. Russ J Herpetol 17: 189194

(Received June 11, 2014 / Accepted July 21, 2014) 